\title{
PERKEMBANGAN AGAMA ISLAM DI DESA TANJUNG SARI KECAMATAN BUAY MADANG TIMUR PADA TAHUN 1938-1968
}

\author{
Riska Anggraini ${ }^{1}$, Hudaidah ${ }^{2}$, Alian Sair $^{3}$ \\ 1,2,3 Universitas Sriwijaya \\ riskaanggrainirtu003@gmail.com
}

\begin{abstract}
Abstrak
Penelitian ini mengungkapkan perkembangan agama Islam di Desa Tanjung Sari yang diawali dengan adanya kolonialisasi Belanda yang mentransmigrankan orang-orang dari Jawa ke Sumatera Selatan. Penelitian ini dilakukan mulai tanggal 15 Maret 2019 hingga 20 April 2019 di Desa Tanjung Sari menggunakan metodelogi penelitian sejarah dengan proses pengumpulan data melalui dokumentasi, wawancara dan studi kepustakaan. Penelitian ini mendapatkan hasil tentang dinamika internal hubungan umat Islam di daerah transmigran yang menunjukkan dua pola perkembangan hubungan, yaitu Hubungan antara agama dengan tradisi lokal dan hubungan antara agama dengan pemikiran keagamaan. Sehingga hubungan antara agama dan budaya dapat digunakan sebagai strategi dalam upaya mengembangkan agama internal di Desa Tanjung Sari dan terdapat naskah tauhid yang dijadikan pedoman untuk pengajaran agama Islam sehingga pola fikir keagamaan masyarakat di Desa Tajung Sari mengalami perkembangan.
\end{abstract}

\section{Kata Kunci: Islam, Transmigrasi, Budaya}

\begin{abstract}
This study reveals the development of Islam in the village of Tanjung Sari, which began with the Dutch colonialism that transmigrated people from Java to South Sumatra. This research was conducted from March 15, 2019 to April 20, 2019 in the village of Tanjung Sari using the methodology of historical research with the process of collecting data through documentation, interviews and literature study. This study gets results about the internal dynamics of the relationship of Muslims in the transmigrant area which shows two patterns of relationship development, namely the relationship between religion and local traditions and the relationship between religion and religious thought. So that the relationship between religion and culture can be used as a strategy in an effort to develop internal religion in Tanjung Sari Village and there is a monotheism script used as a guide for the teaching of Islam so that the pattern of religious thought in the Tajung Sari Village experiences development.
\end{abstract}

Keywords: Islam, Transmigration, Culture.

\section{PENDAHULUAN}

Pengaruh agama Islam di daerah palembang membuat daerah pedalaman juga menerima dampak akan ajaran agama Islam. Sehingga mulai masuk sampai ke daerah Ogan Komering Ulu. Sebelum agama Islam masuk ke daerah Ogan Komering Ulu masyarakat masih menyembah pohon-pohon besar yang dianggap sebagai dewa. Masyarakat mengangap pohon-pohon besar sebagai zat ilahi dari tuhan untuk menghidupi keberlangsungan hidup masyarakat, untuk mengungkapkan rasa syukur 
masyarakat akan manfaat dari pohon-pohon maka mereka menyembah dan mensucikan pohon-pohon yang sangat besar. Pohon-pohon besar dipercaya memiliki kekuatan yang sangat mistis yang memiliki kekuatan yang sangat kuat (Masykuri dan Kuntoyo, 1980/1981: 28).

Seiring perkembangan zaman terjadilah perkembangan masyarakat yang melakukan interaksi dari luar daerah sehingga masuklah pengaruh dari agama Islam. Masuknya agama Islam di daerah Ogan Komering Ulu ini diperjuangkan oleh tiga orang tokoh yaitu Tuan Umar Baginda Saleh yang menyebarkan agama Islam di daerah Mendayun (kurang lebih pada tahun 1575 M-1600 M), Tuan Tanjung Darussalam yang menyebarkan agama Islam di daerah Adumanis Marga Semendawai Suku Tiga dan Tuan Dipulau (Said Hamimul Hamiem) yang menyebarkan agama Islam di Dusun Negara Sakti Marga Semendawai Suku Dua. Para tokoh penyebar agama Islam ini pada awalnya mendirikan tempat-tempat khusus untuk mengajarkan Al-Quran kepada seluruh penduduk. Para penduduk kemudian juga diberikan pelajaran dalam berbagai cabang ilmu pengetahun tentang agama Islam, sehingga agama Islam dapat dengan mudah dipahami oleh penduduk (Gadjahnata dkk, 1986: 218).

Setelah diberikan berbagai pengajaran tentang agama Islam sebagai masyarakat mulai menyebar mencari tempat yang subur untuk digunakan dalam memenuhui kebutuhan hidup. Sehingga perkembangan agama Islam juga mulai menyebar sampai di desa-desa yang berada di Kecamatan Buay Madang Timur yang merupakan salah satu kecamatan di Kabupaten Ogan Komering Ulu Timur. Mula-mula para pemeluk agama Islam menempati pinggiran Sungai Macak yang sangat subur akan perkebunanya. Agama Islam yang berkembang sangat sederhanaa karena masih belom ada tokoh agama yang benar-benar mampu memberikan pengajaran agama seperti di daerah mendayun. Namun, para masyaraka tetap memeluk agama Islam sampai datangnya bangsa Belanda ke daerah Ogan Komering Ulu (OKU) untuk membentuk kolonialisasi.

Pada tahun 1938 awal terbentunya Desa Tanjung Sari dipimpin oleh bapak Abi Soyo. Banyak daerah pada tahun 1938 yang belum mendapat aliran air maka, pada saat itu untuk membuat aliran sungai yang akan mengairi tahan milik warga dibantu oleh tenaga dari Belanda. Dibantunya pembuatan aliran irigasi oleh pihak Belanda pembuatan irigasi dapat berjalan dengan baik. Dengan kondisi tanah daerah transmigrasi yang memiliki ketinggian yang sama dan dapat dialiri air maka pembangunan irigasi berpengaruh dalam keberhasilan produktivitas sawah dan 
perkebunan yang dampaknya memberikan keuntungan besar bagi Belanda dan masyarankat.

Kedatangan para pekerja menjadi awal masuknya agama Islam yang dibawa oleh masyarakat transmigran. Memiliki kehidupan yang baru didaerah transmigrasi membawa dampak negatif karena harus mampu menyesuaikan diri dengan lingkungan yang belum pernah di datangi. Mereka juga harus mampu berkomunikasi dengan baik dengan orang-orang baru yang berasal dari daerah yang berbeda. Keadaan dapat menimbulkan kegelisahan yang dapat menimbulkan tekanan batin yang membuat mereka harus mampu menerima perbedaan.

Pengetahuan agama Islam yang sederhana menyebabkan perkembangan agama menjadi lamban karena dalam kehidupan sehari-harinya selain mereka tidak mampu memahami agama Islam dengan baik, dalam membangun perkembangan agama Islam masyarakat tanjung sari juga masih membawa budaya kejawen yang berasal dari pulau Jawa. Sifat kejawen yang dimiliki masih kental karena untuk sosialisasi mereka hanya sesama antar transmigran. Sifat kejawen tertanam kuat dimasyarakat Jawa, pihak Belanda pun tidak melarang masyarakat untuk mempersatukan antara budaya dan agama. Sehingga agama yang dimiliki pada masyarakat Jawa akan memiliki hubungan yang erat dengan budaya maka ada perkembanganya agama yang dianut oleh masyarakat jawa akan diiringi dengan budaya yang ada dan terjadilah persilangan yang kemudian muncul nama kejawen kemudian menyebabkan secara bersamaan mewarnai kehidupan masyarakat Jawa. Terkadang persilangan tersebut membuat masyarakat Jawa untuk dapat memilih agama atau budaya sebagai pegangan hidupnya. Namun fonomena tidak membuka sebuah konflik di tengah-tengah masyarakat Jawa, mereka cenderung untuk memilih jalan tengah sesuai keyakinan masing-masing.

\section{METODE PENELITIAN}

Mengkaji sejarah tidak hanya untuk mendeskripsikan suatu peristiwa saja tetapi harus mampu merangkai suatu kejadian dengan cara mengkaji, menganalisis berbagai kondisi lingkungan yang ada, lingkungan budaya yang ada lalu mencari faktor-faktor apa saja yang dapat mempengaruhi suatu proses pristiwa sejarah. Untuk mendapatkan suatu fakta sejarah dibutuhkan langkah-langkah untuk mendukung penelitian sejarah. Karena tidak mudah untuk mendapatkan fakta-fakta sejarah jika tanpa menggunakan langkah-langkah dalam metodologi sejarah. 
Penelitian digunakan untuk menyelidiki suatu keadaan yang memiliki nilai. Penelitan tentang suatu pristiwa untuk mengungkapkan dapat dilakukan melalu observasi ke tempat terjadinya suatu peristiwa. Penelitian memiliki perananamat penting dalam memberikan sumbangan ilmu sehingga perlu dilakukan sebaik mungkin agar dapat dimanfaatkan untuk pembangunan ilmu pengetahun. Dalam melakukan penelitian ada saat peneliti tidak menemukan data yang dibutuhkan karena untuk mendapatkan data yang terpercaya dan asli. Sehingga hasil dari penelitan yang sulit dengan melalui berbagai masam prosedur harus dihargai. Tidak ada satu negara yang sudah maju dan berhasil dalam pembangunan, tanpa melibatkan dalam bidang penelitian (Nazir, 2011:24).

Penelitian dengan menggunakan metodologi sejarah mengungkapkan keadaaan yang kritis, perkembangan yang bersifat kronologis, serta pengalaman dimasa lampau dan menampung dengan cukup teliti dan hati-hati tentang bukti validitas dari sumber sejarah. Ada empat tahap metodologi sejarah yaitu pengumpulan sumber (heuristic), kritik sumber, interprestasi dan histografi. Perlu menggunakan metodologi sejarah agar tahapan untuk melakukan penelitian menjadi lebih mudah dan data yang didapat mendekati kebenaran yang sesuai dengan kejadian.

\section{HASIL DAN PEMBAHASAN}

Menurut Faisal (1995:82) agama merupakan sistem nilai dan tata cara ibadah (ritual) kepada Tuhan Yang Maha Esa serta tata cara berperilaku sehari-hari (ahlak dan budi pekerti) terhadap sesama manusia, lingkungan, dan alam yang dianut oleh manusia sebagai pelaksana kegiatan-kegiatan yang memiliki tujuan atau maksud tertentu dalam interaksinya dengan manusia atau mahluk lain. Menurut Khotimah (2014:122) makna agama memiliki arti yang cukup banyak, diantaranya agama berasal dari bahasa sangsekerta yang terbagi menjadi $a$ dan gam. $a=$ tersusun rapi. Ada juga yang mengartikan $a=$ menolak, tidak, dan bukan, sedangkan arti dari gam = meninggalkan yang berarti tidak pergi dan menetap. Dalam bahasa lain kata gam memiliki persamaan dengan go dalam bahasa Inggris dan gaan dalam bahasa Belanda. Muncul pula anggapan yang mengatakan bahwa agama adalah teks atau kitab suci, karena agama memang harus mempunyai kitab suci sebagai pedoman.

Sedangkan untuk pengertian Islam menurut Abdalati (1983:13) Islam berarti kepatuhan kepada kehendak Allah dan kemauan Allah, serta taat kepada hukumnya. Sedangkan menurut Departemen Agama RI (2002:9) secara etimologis Islam berasal 
dari bahasa Arab aslama yuslimu. Islam yang berarti penyelamat hidup,menyerahkan, taat, dan setia. Adapula yang berpendapat bahwa Islam berasal dari kata slim yang mengandung arti selamat, damai dan sejahtera. Pendapat tersebut memiliki hubungan yang mendasar dalam penyerahan diri kepada Allah Yang Maha Pencipta. Dengan demikian arti yang terkandung dalam perkataan Islam adalah kedamaian, kesejahteraan, keselamatan, penyerahan (diri), dan kepatuhan.

Jadi berdasarkan pengertian diatas dapat disimpulkan bahwa agama Islam adalah tata nilai dan pedoman manusia berisi tentang ajaran menjalankan perintahnya dan menjauhi segala larangannya yang ditentukan oleh Allah Swt. Kepatuhan yang dilakukan seorang muslim akan berdampak pada kedamaian dalam kehidupan bermasyarakat karena agama Islam mengajarkan bagaimana cara berperilaku agar tidak menimbulkan konflik. Keharusan seorang muslim yang percaya akan keberadaan Allah Swt sehingga menciptakan keselamatan bersama.

Penyebaran agama Islam melalui pendidikan yang mengajarkan tentang ilmu agama Islam. Pendidikan Islam dimulai pada saat islam sudah mulai dianut oleh masyarakat, namun pendidikan Islam pada saat itu bukan berbentuk kelembagaan namun pada saat itu masih dalam bentuk yang sederhana yang menyesesuaikan dengan budaya yang berkembang dimasing-masing daerah. Pada saat perkembangan pendidikan Islam semakin maju masyarakat mulai mengenal tulisan Arab bahkan berkembang tulisan Arab gundul dengan menggunakan bahasa daerah. Sehingga terjadilah akulturasi antara sastra Islam dengan sastra yang berada di nusantara yang menghasilkan naskah-naskah dengan menggunakan tulisan Arab dan berbahasa daerah. Naskah-naskah yang dihasilkan berkaitan dengan berbagai ilmu yang berkaitan dengan agama Islam. Seperti seorang murid atau santri mendatangi gurunya atau seorang guru melakukan kunjungan keliling untuk berdakwah dan sebagainya (Wahyuni, 2013: 131).

Pendapat diatas sesuai dengan contoh penyebaran agama Islam yang Ada di Desa Tanjung Sari. Dalam penyebaran agama Islam masyarakat membentuk perkumpulan pembelajaran agama Islam hanya untuk anak-anak untuk diajarkan cara memahami ajaran Islam. Pengjaran ini pada awalnya hanya sebagai pengenalan doa-doa dan menghafal surat pendek.

Para trasmigran dalam penyaluran agama Islam hanya memfokuskan dibidang pendidikan anak-anak. Hal yang membuat anak-anak lebih difokuskan dalam pembelajaran agama Islam karena para orang tua disibukan bercocok tanam. Dalam perkembangan pendidikkan agama Islam yang berada di Desa Tanjung Sari tidak 
memberikan dampak yang besar karena penyebaran hanya berada dilingkungan transmigrasi saja. Orang Jawa yang ditransmigrankan tidak memiliki sifat untuk berambisi dalam menyebarkan agama Islam, mereka lebih mengutamakan dalam bercocok tanam.

Menurut sejarah terbentuknya desa berasal dari perkumpulan kecil dari masyarakat yang memiliki tingkat berfikir yang mendorong untuk memajukan daerahnya. Mereka membentuk identitas yang unik untuk wilayahnya dengan memiliki tradisi adat istiadat dan norma sendiri yang mengakar kuat. Persatuan yang kuat mengembakan sikap yang relatif mandiri tanpa campur tangan kekuasaan dari luar. Terbentukanya desa juga dapat menjadi wadah partisipasi rakyat dalam aktivitas politik pemerintahan seperti melaksanakan pemilihan umum dan media interaksi politik. Terlebih sebagian besar wilayah Indonesia terletak di wilayah Desa. Partisipasi masyarakat pedesaan diperlukan untuk pembangunan sekaligus akan dapat meningkatkan penghidupan masyarakat di pedesaan (Luthfia, 2013: 138).

Dengan perkumpulan yang kecil dan memilki pemikiran untuk mengembangkan daerah maka terbentuk Desa Tanjung Sari. Desa ini terbentuk dari orang-orang yang di transmigrankan oleh Belanda pada masa kolonial pada tahun 19381939 oleh para transmigran dari daerah Jawa Timur. Mereka datang ke daerah yang sekarang disebut Desa Tanjung Sari melalui program Transmigrasi oleh Belanda. Mereka adalah orang-orang transmigran yang nantinya dijadikan tenaga buruh tani oleh Belanda. Para transmigran tersebut tiba didaerah yang pada awalnya masih berbentuk hutan. Kebanyakan orang Jawa yang dipilih karena orang Jawa dianggap masyarakat yang benar-benar giat bekerja keras untuk menjadi sukses dan makmur hidupnya. Pada saat itu nama Desa Tanjung Sari tidak langsung terbentuk. Pada awalnya nama Desa Tanjung Sari dikenal sebagai Jebol Deso yang artinya membuka desa. Nama Desa Tanjung Sari ini diambil dari nama desa yang ada di Jawa Timur yang pernah ditinggali oleh para transmigran.

Sebuah desa memiliki peran yang penting dalam mengatur pokok perekonomian lumbung pangan untuk memenuhi kebutuhan di daerah lain. Terdapat banyak para pekerja yang memiliki sifat yang pantang menyerah sehingga banyak menghasilkan bahan mentah. Sebuah desa juga memiliki karakteristikk yang berbedabeda karena mereka terbentuk dari persamaan keyakinan, pemahaman, pengetahuan dibidang agraris. Sehingga budaya lokal tetap terjaga untuk mencirikan daerah tersebut (Nursetiawan: 74). 
Desa Tanjung Sari bisa disebut dengan daerah Belitang yang memiliki tingkat kesuburan tanah yang tinggi. Pada tahun 1937 daerah ini diperhatikan oleh pihak Belanda karena akan dijadikan sebagai daerah pertanian. Perubahan yang akan dilakukan oleh Belanda perlu memiliki tenaga ahli untuk membantu merubah daerah ini agar bisa dimanfaatkan sebaik-baiknya maka pihak Belanda mendatangkan orang-orang yang berasal dari Pulau Jawa untuk menjadi pekerja di area Belitang.

Pada tahun 1938 awal terbentunya Desa Tanjung Sari ini dipimpin oleh bapak Abi Soyo. Banyak daerah pada tahun 1938 yang belum mendapat aliran air maka, pada saat itu untuk membuat aliran sungai yang akan mengairi tahan milik warga dibantu oleh tenaga dari Belanda. Dengan dibantunya pembuatan aliran irigasi oleh pihak Belanda pembuatan irigasi dapat berjalan dengan baik. Dengan kondisi tanah daerah transmigrasi yang memiliki ketinggian yang sama dan dapat dialiri air maka pembangunan irigasi berpengaruh dalam keberhasilan produktivitas sawah dan perkebunan yang dampaknya memberikan keuntungan besar bagi Belanda dan masyarankat. Pertanian tidak akan maju tanpa adanya irigasi oleh sebab itu pemerintah kolonial Belanda tetap mengawasi masyarakat dalam memanfaatkan irigasi.

Tabel 1. Daftar kepala desa yang pernah memerintah di Desa Tanjung Sari

\begin{tabular}{ccc}
\hline NO & NAMA & TAHUN \\
\hline 1 & Abi Soyo & $1939-1955$ \\
2 & Marto Sudarsi & $1955-1961$ \\
3 & Sastro Utomo & $1961-1962$ \\
4 & Supat & $1962-1964$ \\
5 & Paiso Wijiyo & $1965-1966$ \\
6 & Lasimen & $1966-1968$ \\
7 & Wosono & $1968-1974$ \\
8 & Romli & $1974-1981$ \\
9 & Paino & $1981-1984$ \\
10 & Sumiati & $1984-1992$ \\
11 & Abdulah Safi'i & $1992-1996$ \\
12 & Parman PJS & $1996-1998$ \\
13 & Feri Edwin & $1998-2006$ \\
14 & Feri Edwin & $2006-2011$ \\
15 & Des Arpan & $2011-$ \\
\hline
\end{tabular}


Kedatangan para pekerja menjadi awal masuknya agama Islam yang dibawa oleh masyarakat transmigran. Memiliki kehidupan yang baru didaerah transmigrasi membawa dampak negatif karena harus mampu menyesuaikan diri dengan lingkungan yang belum pernah di datangi. Mereka juga harus mampu berkomunikasi dengan baik dengan orang-orang baru yang berasal dari daerah yang berbeda. Keadaan ini dapat menimbulkan kegelisahan yang dapat menimbulkan tekanan batin yang membuat mereka harus mampu menerima perbedaan.

Pengetahuan agama Islam yang sederhana menyebabkan perkembangan agama menjadi lamban karena pada saat Belanda sudah menanamkan kekuasaannya untuk membuka lahan pertanian di daerah Desa Tanjung Sari. Tentu saja mempengaruhi perkembangan agama Islam yang semula sudah lamban dengan ditambahnya kebijakan Belanda yang mengharuskan masyarakat transmigran harus tetap giat berkerja.

Pada saat bapak Abi Soyo menjadi kepala desa pertama kali tidak terlihat perkembangan agama Islam karena mereka berfokus untuk berkerja. Keadaan geografis pada saat itu juga kurang mendukung karena masih banyak lahan yang berbentuk hutan yang perlunya dirubah menjadi daerah pertanian. Pada dasarnya masyarakat Jawa yang ditransmigrasikan ini memiliki sikap nerimo. Maksud dari nerimo adalah mereka datang ke Desa Tanjung Sari ini untuk diperkerjakan tidak untuk mengetahui agama Islam yang mendalam.

Agama Islam dalam penyabaran di Desa Tanjung Sari tidak memaksa para pengikutnya untuk menerima ajaran Islam. Orang-orang yang ditransmigrasikan oleh Belanda ini ada yang beragama Islam yang telah ia anut di Pulau Jawa. Namun, dalam memahami secara mendalam tentang wajib dan sunnah dalam agama Islam para transmigran khususnya di Desa Tanjung Sari belum sepenuhnya memahami dasar agama Islam. Masyarakat yang ditrasmigrankan hanya mengenal bahwa agama Islam adalah sebuah agama tidak untuk dijadikan sebagai pedoman hidup maka mereka tidak tau mana yang halal dan haram untuk kehidupan.

Dalam kehidupan sehari-harinya selain mereka tidak mampu memahami agama Islam dengan baik, dalam membangun perkembangan agama Islam masyarakat tanjung sari juga masih membawa budaya kejawen yang berasal dari pulau Jawa. Sifat kejawen yang dimiliki ini masih kental karena untuk sosialisasi mereka hanya sesama antar transmigran. Sifat kejawen tertanam kuat dimasyarakat Jawa, pihak Belanda pun tidak melarang masyarakat untuk mempersatukan antara budaya dan agama. Sehingga agama yang dimiliki pada masyarakat Jawa akan memiliki hubungan yang erat dengan budaya 
maka ada perkembanganya agama yang dianut oleh masyarakat jawa akan diiringi dengan budaya yang ada dan terjadilah persilangan yang kemudian muncul nama kejawen kemudian menyebabkan secara bersamaan mewarnai kehidupan masyarakat Jawa. Terkadang persilangan tersebut membuat masyarakat Jawa untuk dapat memilih agama atau budaya sebagai pegangan hidupnya. Namun fonomena ini tidak membuka sebuah konflik di tengah-tengah masyarakat Jawa, mereka cenderung untuk memilih jalan tengah sesuai keyakinan masing-masing.

Bagi masyarakat Suku Jawa agama dan kebudayaan secara bersamaan dijadikan sebagai sarana rasa terima kasih dan meminta perlindungan. Uniknya, agama dan budaya dapat hidup berdampingan tanpa adanya benturan yang negatif, hal ini bisa dilihat dari kegiatan keagamaan yang masih terbungkus budaya atau sebaliknya di komunitas lokal masyarakat Suku Jawa, sebagai contoh seperti perayaan (kenduri) yang dilakukan orang Islam yang masih membakar kemenyan (sesajen) pada hari sebelum perayaan (kenduri) dan setelah Acara perayaan akan diadakan makananmakan besar (selamatan). Budaya ini tetap berjalan untuk pemenuhan batin masyarakat jawa, sehingaa budaya sesajen masih kuat (Kurniawan, Mulawarman, \& Kamayanti, 2015).

Budaya lama yang masih menggunakan sesajen untuk tempat-tempat keramat atau ingin meminta kelacaran dalam melakukan proses penanaman padi. Pembuatan sejasen ini rata-rata dilakukan oleh masyarakat transmigran yang beragama Islam dengan mengubah bacaan atau doa-doa ketika ingin meminta suatu kelancaran. Secara hukum Islam tentu menyatukan antara budaya dengan aturan yang ada diagama Islam tidak diperbolehkan namun masyarakat tetap memiliki keyakinan untuk melakukan budaya pembuatan sesajen.

Seorang yang sudah beragama Islam akan meminta pertolongan dan menyerahkan diri kepada yang maha kuasa. Sebagai seseorang yang susah melepas budaya kejawen ada sebagaian Suku Jawa yang yang memperjuangkan perkembangan agama Islam dengan menggunakan pendekatan akulturasi sesajen. Suasana Islam menjadi berwarna dengan adanya penggabungkan warisan pra-Islam (Ghofur, 2011:159-160).

Hal itu sependapat dengan Haryanto yang menggagap hubungan yang terjalin harmonis antara agama dan tradisi kejawen dapat menjadi simbol kearifan lokal yang memiliki nilai. Pada saat proses penerimaan Islam di suku Jawa akulturasi antara agama Islam dan budaya lokal yang kuat sehingga tidak dengan mudah untuk melepaskan 
salah satunya. Melihat suku Jawa sulit sekali untuk melepaskan budaya kejawen yang sudah melekat didalam kehidupan sehari-hari maka mereka berhasil mengembangkan unsur-unsur agama yang disatukan dengan kebudayaan sehingga budaya dan agama masih bertahan. Akibat dari penyatuan ini maka menjadi strategisnya dakwah Islam dengan menggabungkan keagamaan lokal (Hariyanto, 2015: 45).

Dutney juga berpendapat demikian bahwa agama melibatkan sesuatu yang sakral yang tidak bisa di ubah dengan mudahnya. Pembentukan seluruh agama yang sudah bercampur dengan budaya tidak hanya berasal dari aturan yang sudah ada namun juga berasal dari ritual yang ada. Dengan demikian suatu yang sudah terbentuk oleh sistem budaya yang telah ada pada zaman dahulu lalu diteruskan dimasa selajutnya dapat membentuk kehidupan dan pemikiran untuk tetap menyatukan budaya dan agama (Dutney, 2006).

Pada tahun 1951 datanglah tokoh yang bernama Bapak Suyato ia merupakan transmigran yang berasal dari Jawa Tengah, namun pada awalnya ia tidak di transmigrankan di Desa Tanjung Sari tapi di Kurungan Nyawa. Pindahnya beliau dikarenakan pada saat itu masih ada area tanah yang kosong dan tidak memiliki harga jual. Datangnya bapak Suyato sekaligus membuat podok kecil untuk mengaji anak-anak di area Tanjung Sari. Pada saat itu tidak ada baca tulis arab yang seperti saat ini. Proses mengaji hanya sebatas menghafal surat-surat pendek. Jadi, walaupun anak-anak sudah banyak menghafal surat-surat pendek mereka tidak tau bagaimana cara menulis dengan menggunakan huruf Arab.

Keadaan pola fikir yang semakin maju membuat usaha untuk terciptanya pengembangan pendidikan Islam dilingkungan transmigran. Namun sifat kejawen masih melekat pada diri masyarat transmigran. Ternyata kebutuhan pendidikan agama Islam penting yang membuat masyarakat menyadari tentang pedoman hidup di akhirat. Menurut Moons et al (2018) hubungan yang terjalin antara agama dengan menentukan kwalitas hidup didasarkan dari diri seseorang yang telah menganggap seberapa pentingnya posisi agama itu. Maka mereka harus menjalin hubungan untuk dapat melengkapi kualitas hidup.

Pada perkembangan agama Islam di Desa Tanjung Sari selain adanya seseorang yang mamahami agama Islam sebagai guru didukung pula minat yang mendalam dari orang tua untuk memberikan pengajaran agama bagi anak-anaknya. Agama Islam juga sudah di anut oleh penduduk asli daerah Belitang maka akan dapat terjadi interaksi 
saling tukar fikiran tentang agama Islam yang telah terbentuk sejak awal di daerah Desa Tanjung Sari dengan masyarakat.

Pendidikan dibidang agama Islam dalam interaksi sesama muslim untuk mengkomunikasikan tujuan akan disangkutkan dengan masa lalu. Masyarakat lokal dengan pendatang tetap saling bertukar fikiran didalam perkembangan pendidikan Islam, mengingat mereka bersama-sama berjuang mengembangkan agama Islam ditengan masa kolonial. Berjuang membangun untuk pertumbuhan agama Islam merupakan misi bersama pada masa kolonial (Ashaari et all, 2012).

Pada awalnya masyarakat Desa Tanjung Sari hanya memiliki satu tokoh sebagai pengajaran agama Islam sehingga pengjaran hanya didasakan atas pengetahun satu tokoh. Sehingga muncul fikiran untuk mencari tambahnan pedoman untuk lebih memperkuat ajaran agama Islam sehingga dicarilah sebuah naskah tauhid untuk dijadikan sebagai tambahn pedoman untuk pebelajaran agama Islam.

Penciptaan sebuah naskah memang mengandung banyak sekali makna. Isi yang terkandung didalamnya selalu diselaraskan dengan kehidupan masyarakat yang menerapkan naskah tersebut. Naskah diciptakan untuk dipergunakan sesuai kebutuhan hidup. Terdapat fungsi sosial yang tinggi untuk mengatur tatanan masyarakat agar memiliki pola yang teratur. gambaran yang dimiliki oleh isi naskah memuat ajaranajaran hidup, tata cara berperilaku, dan menyesuaikan dengan kepercayaan yang dianut (Damayanti dan Haryadi, 2007: 67).

Naskah merupakan suatu keutuhan dan mengungkapkan pesan. Pesan yang terbaca dalam teks secara fungsional berhubungan erat dengan filsafat hidup dan dengan bentuk kesamaan yang lain. Dilihat dari kandungan maknanya, wacana yang berupa teks kelasik itu mengemban fungsi tertentu, yaitu membayangkan pikiran dan membentuk norma yang berlaku, baik bagi orang sejaman maupun bagi generasi mendatang (Baried, 1985: 5).

Penemuan sebuah naskah dapat mencirikan bahwa masyarakat tersebut sudah memiliki pola hidup yang berkembangan. Seperti di Desa Tanjung Sari telah ditemukan sebuah naskah yang digunakan untuk pembelajaran agama Islam dan diterapkan dalam kehidupan sehari-hari. Sebagai bahan pembelajaran agar masyarakat desa Tanjung Sari mampu memahami agama Islam lebih baik dari sebelumnya. Naskah ini berisi tentang ilmu tauhid yang digunakan sebagagi pedoman dalam mendekatkan diri kepada Allah Swt. 
Tauhid adalah pengakuan akan kesatuan Allah, Yang Tak Terbagi, Yang Mutlak dan Satu-Satunya yang Nyata. Doktrin ini adalah inti dari Islam, dan memang, itu adalah dasar keselamatan. Tauhid digunakan dalam referensi kepada Allah, secara teknis berarti menyadari dan memelihara kesatuan Allah dalam semua tindakan manusia, yang secara langsung atau tidak langsung berkaitan dengan-Nya. Oleh karena itu, Tauhid adalah kepercayaan bahwa Allah adalah Satu, tanpa pasangan dalam kekuasaan dan tindakan-Nya (Ruboobeeyah), Satu tanpa kesamaan dalam esensi dan atribut-Nya (Asmaa wa Sifaat), dan Satu tanpa pesaing dalam keilahian-Nya dan dalam ibadah (Ulooheyah / Ebaadah) (Salim and Syahrul, 2015: 22).

Naskah tauhid ini unik untuk pembelajaran agama Islam karena disesuaikan dengan bahasa yang berkembang di Desa Tanjung Sari yaitu Bahasa Jawa dengan huruf Arab. Naskah ini didatangkan dari daerah Bandung yang diinfaqkan ke bapak Lasimen. Pada saat itu naskah ini hanya di baca oleh yang ahli agama lalu ilmu yang terkandung didalamnya diterapkan dalam proses mengaji anak-anak. Sehingga dari dini pola fikir anak-anak akan tertanam agama Islam. Naskah ini pada saat ditemukan masih tersimpan rapi di rumah keturunan Bapak Lasimen. Beliau Adalah seorang mantan kepala Desa Tanjung Sari yang pertama kali menerapkan pembelajaran dengan berpedoman pada naskah untuk lebih memperjelas ajara agama Islam.. Berikut ini adalah bagian dari naskah yang masih bisa dibaca dan diambil kandungan ilmu agamanya.

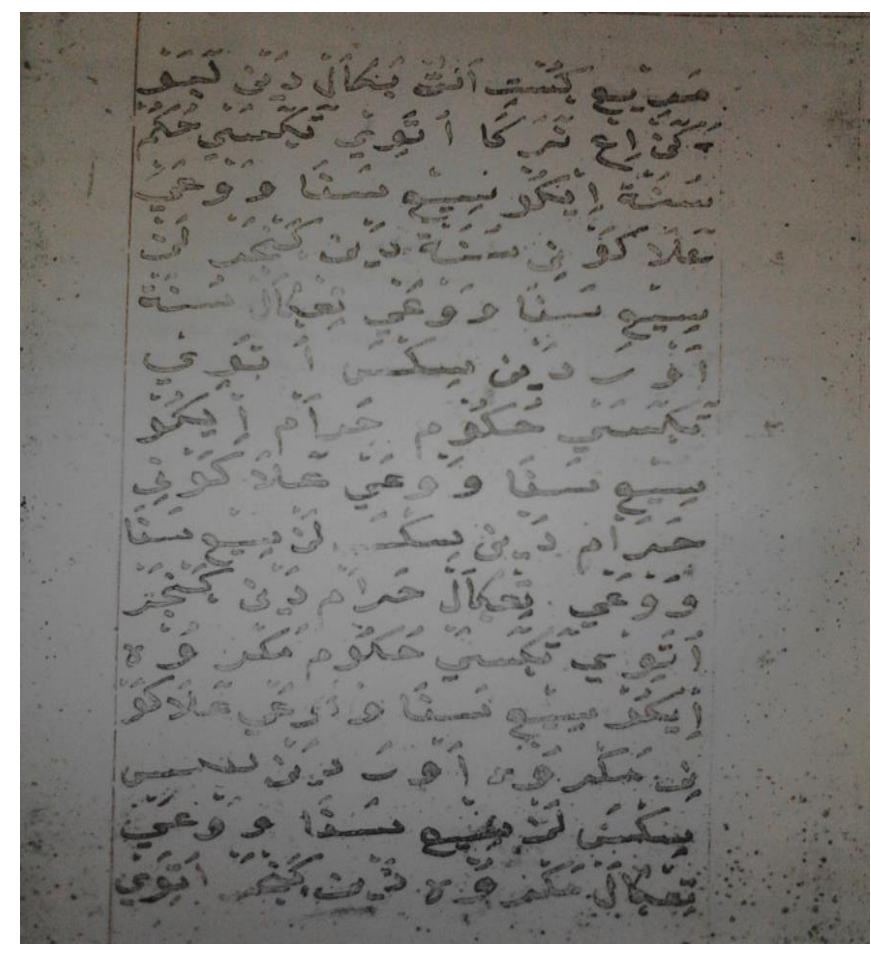

Gambar 1. Naskah Tauhid 
Artinya:

- Bahasa Jawa Halus

Mareng gusti akese bakal ben lakoni eng neroko utawi tegese hukum sunnah iku seng sopo wonge lakoni sunnah eng ganjar lan seng sopo wonge nenggal ne sunnah ora disikso. Utawi tegese hukum harom iku seng sopo wonge lakoni harom iku di sikso. Lan sopo wonge ninggalne harom eng diganjar. Utawi tegese hukum makhruf iku seng sopo wonge lakoni makhruf ora di sikso lan seng sopo wonge lakoni makhruf ben di ganjar.

- Bahasa Indonesia

“ maha suci allah menegaskan yang menyebabkan orang masuk neraka. Ditegaskan orang yang melakukan sunnah akan mendapatkan pahala bagi orang yang tidak melakukan sunnah tidak akan disiksa. Ditegaskan pula hukum haram itu barang siapa yang melakukan perbuatan haram akan disiksa dan orang yang meninggalkan perbuatan haram akan mendapatkan pahala. Ditegaska pula pada hukum makhruf barang siapa yang melakukan perbuatan makhruf tidak akan di siksa dan yang melakukan hukum makhruf akan mendapatkan pahala.

Dari terjemahan naskah di atas dapat ditegaskan bahwa aturan dari agama Islam di bagian awal naskah ini bahwa setiap perbuatan yang kita lakukan di masa dunia ini akan mendapat balasan di alam akhirat nantinya. Baik perbuatan kita yang melakukan perbuatan yang baik dan buruk akan ada imbalan yang sudah ada aturannya. Untuk mencegah adanya perbuatan yang tidak sesuai dengan agama dalam naskah ini diajarkan kita untuk mendekatkan diri kita kepada allah swt. Kita diajarkan untuk mendekatkan diri dan menuruti aturan yang sudah diaturnya. Hal ini juga akan berkaitan dengan tingkah laku yang kita lakukan. Untuk menjaga dan mencegah agar tidak timbul suatu perbuatan yang tidak sesuai dengan aturan agama Islam. Suatu hal yang telah tertulis yang ada di dalam naskah bahwa nabi telah memiliki sifat amanah sebagai orang kepercayaan Allah dalam menyebarkan agama Islam. Sifat ini juga dapat kita tiru dalam kehidupan kita sehari-hari. Memang tentunya untuk memiliki sifat ini sebagian orang tidak mampu memilikinya. Jika kita melihat keadaan dasar manusia yang berbeda dalam interaksinya yang dalam interaksi dapat membentuk sifat yang berbeda - beda. Namun jika kita ingin berusaha dalam menjalankan sebuah kehidupan kita perlu punya landasan untuk bagaimana cara kita bertingkah laku di dalam masyarakat. Masyarakat yang baik adalah sebuah kumpulan individu yang saling memperhatikan suatu tatanan 
yang ada di dalam lingkungan sekitaar untuk menilai baik dan buruknya hal yang akan di terima nantinya.

Hal yang tertulis di dalam naskah pun sudah jelas jika kita mendekatkan diri kepadanya (Allah Swt) mudah mudahan atas izinnya apa yang kita inginkan akan terwujud. Manusia juga perlu berfikir allah tidak akan memberikan suatu yang kita inginkan jika kita tidak berusaha dan tidak mematuhi aturanya. Jika kita ingin segala hal dilancarkan maka kita perlu mendekatkan diri padanya. Apa lagi pada zaman sekarang banyak yang tidak mematuhi aturanya jika kita berfikir pembentukan aturan yang ada di dalam naskah ini mempunyai tujuan untuk mengatur cara kita agar dekat dengan tuhan. Tingkah laku kita yang ada di dalam masyarakat ini menjadi penilaiaan penting dalam pendekatan diri kita. Jika kita memiliki pola pergaulan yang mejauhkan diri kita maka secara tidak langsung kita akan berada jauh dari ketentuanya secara tidak langsung orang yang berada jauh dari ketentuanya merupakan orang yang kurang memiliki etika dan tata krama.

Agama Islam yang dimaksud di sini bertujuan mengatur tatanan prilaku yang sesuai dengan tindakan agama. Memang secara penguasaan isi mbah osin tidak mendalami naskah ini namun menurut yang dia tau ada hal yang terkandung di dalam isi naskah ini seperti cara bertindak di dalam menjalankan agama ketika kita bergaul di dalam masyarakat kita memerlukan agama sebagai acuaan dalam menselaraskan lingkungan dengan kepribadiaan individu. Aturan yang dimaksud ini seperti seorang individu ketika beradaa didalam masyarakat harus menjaga tatakelakuaan sesuai agama Islam seperti seorang yang bukan muhrim tidak diperbolehkan melanggar aturan yang telah ditetapkan agama Islam. Karena jika seseorang yang telah melanggar agama Islam dia akan mendapatkan ganjaran. Naskah ini di bawa ke Sumatra saat pembawanya itu mendirikan sebuah desa. Ini bisa jadi sebuah buku pedoman bertata kelakuan untuk masyarakatnya pada nantinya.

Ajaran agama Islam menggabungkan antara kelancaran kehidupan dunia dan Akhirat sehingga memiliki keseimbangan yang menjadi pelengkap antara kebutuhan fisik dan spiritual dengan masing-masing tujuannya. Kebutuhan fisik yang di butuhkan oleh manusia terdiri dari kepuasan material. Sedangkan kebutuhan spiritual berkaitan dengan kepuasan sosial dan intelektual untuk menenangkan batin manusia. Sebagai kebutuhan dari kehidupan aspek spiritual harus ditempatkan pada tempat yang lebih tinggi karena aspek menuntut pemenuhan kebutuhan dari ikatan cinta. Jika hati manusia tidak dipenuhi dengan cinta akan selalu muncul rasa gelisah, tidak pernah 
merasa cukup dan tidak bisa merasa bahagia. Sehingga agama sebagai pemenuhan kebutuhan spiritual lebih diprioritaskan dikehidupan dunia agar menjadi lebih bermakna (Amaliah, Aspiranti, \& Purnamasari, 2015).

Norma agama yang muncul dimasyarakat pada dasarnya dikaitkan dengan interaksi sesama antar kelompok yang telah membentuk pola perubahan. Pola perubahan yang terjadi mendorok munculnya ide perubahan keanekaragaman bahasa yang digunakan untuk sarana berkomunikasi. Akibat didukung dengan mudahnya berkomunikasi maka interaksi antar kelompok mudah untuk melakukan pembauran (Burbridge, Dixon, \& Soewardi, 1981).

Dalam agama Islam kecerdasan spiritual akan mendorong kehidupan yang harmonis pada diri seseorang. Keteguhan hati yang dimiliki akan melahirkan kepercayaan yang murni. Pada dasarnya seseorang yang benar-benar sudah percaya dengan agama Islam akan mampu membangun ikatan yang kuat antar sesama muslim. Pola prilaku yang dapat timbul cenderung memikirkan antara duniawi dan akhirat (Rahman \& Shah, 2015).

Faktanya akan muncul kepercayaan pada diri sendri jika mematuhi segala peritah dari Allah Swt. Sebagai seseorang yang patuh terhadap ketetapan yang diberikan oleh Allah akan semakin yakin tentang apa yang telah diberikan. Dengan kata lain seseorang harus mempunyai iman sebagai indikator untuk kemeyakini kuas tuhan. Karena yang terpentig dari sebuah agama adalah kepercayaan terhadap Islam sebagai pokok keharmonisan (Baharuddin \& Ismail, 2015).

Untuk Mengetahui Tentang Perkembangan agama Islam Yang Ada Di Desa Tanjung Sari peneliti mengabil sumber seperti data wawancara dengan bapak jemu yang merupakan tokoh yang dituakan, data dari dinas penerangan, dan data dari jumlah pembayaran zakat yang ada di masjid Darusalam sebagai berikut :

Tabel 2. Penganut Agama Islam di Desa Tanjung Sari

\begin{tabular}{lrcc}
\hline NO & 1938 & 1951 & 1967 \\
\hline 1. & 21 Keluarga & 631 Orang & 750 Orang \\
\hline
\end{tabular}

Dari data diatas dapat dilihat perkembangan penganut agama Islam yang ada di Desa Tanjung Sari memiliki tingkat kemajuan yang pesat. Karena perkembangan penganut agama Islam tidak hanya didorong oleh penduduk Awal saja adanya faktor transmigrasi lanjutan yang dilakukan oleh pemerintah pada tahun 1951 yang membuat jumlah penduduk semakin bertambah. 
Semakain bertambahnya penganut agama Islam berpengaruh juga dibidang bangunan beribadah. Kebutuhan pokoh ini membuat penduduk memiliki pemikiran untuk memenuhi kebutuhan rohani. Selain untuk dijadikan tempat ibadah. Bangunan yang awalnya sederhana ini dijadikan perkumpulan untuk tukar fikiran antara masyarakat. Pada zaman dulu bentu bangnan masih terbuat dari alas bambu dengan atap jerami. Kesederhanaan tempat ini mampu memenuhi kebutuhan rohani masyarakat. Seiring bertambahnya masyarakat pendatang maka semakin luas juga kebutuhan daya tampung untuk melaksanakan ibadah maka dalam perkembangan berkelanjutan dibuatlah tempat ibadah yang lebih besar. Dalam perkembangan pembuatan tempat ibadah bisa dilihat pada tabel dibawah ini :

Tabel 3. Jumlah Tempat Ibadah di Desa Tanjung Sari

\begin{tabular}{ccc}
\hline Tahun & Langgar & Masjid \\
\hline 1938 & - & - \\
1941 & 1 & - \\
1952 & 3 & 1 \\
1967 & 7 & 1 \\
\hline
\end{tabular}

Sejalanya kebutuhan tentang agama sebagai kebutuhan untuk meningkatkan kualitas hidup maka terbentuk pengajaran pendidikan agama yang dilakukan secara nonformal hanya mengandalkan minat bagi siapa yang ingin mempelajari agama. Guru yang melakukan pengajaran mula-mulai menanamkan dasar-dasar tentang keimanan dan cara beribadah dalam agama Islam. Fokus guru dalam pembelajaran ini adalah anak-anak yang masih memiliki pola fikir yang mudah diantur. Dengan adanya pembelajar yang sederhana ini telah membuktikan bahwa masyarakat transmigran mampu menciptakan daerah tempat tinggalnya memiliki nilai kepercayaan dengan agama Islam.

Pada perkembangan agama Islam di Desa Tanjung Sari selain adanya seseorang yang mamahami agama Islam sebagai guru didukung pula minat yang mendalam dari orang tua untuk memberikan pengajaran agama bagi anak-anaknya. Agama Islam juga sudah di anut oleh penduduk asli daerah Belitang maka akan dapat terjadi interaksi saling tukar fikiran tentang agama Islam yang telah terbentuk sejak awal di daerah Desa Tanjung Sari dengan masyarakat. 
Perkembangan Agama ..... Riska Anggraini, Hudaidah, Alian Sair

\section{KESIMPULAN}

Kebutuhan manusia dalam memenuhi segala keperluan kebutuhan rohani mendorong masyarakat jawa untuk memiliki pedoman hidup yang senpurna. Pada saaat ditrasmigrasikan mereka hanya mempersiapkan agama Islam dengan seadanya atas dorongan yang kuat ereka mencari pedoman sumber untuk memperjelas hukum-hukum Islam. Maka dicarilah sebuah naskah tauhid untuk dipelajari kadunganya dalam memahami agama Islam. Naskah ini memang sudah tidak lengkap lagi ada halaman yang sudah sobek dan ada halaman yang sudah hilang karena sudah lamanya keberadaan naskah jadi memungkinkan terjadi ketidak lengkapan naskah yang dimakan usia lama. Namun dari halaman yang tersisah ini masih sanggat jelas keadaan naskah dari tulisan yang masih bisa dibaca dengan jelas. Isi dari naskah ini adalah bagaimana cara kita sebagai manusia untuk senantiasa mendekatkan diri kepada tuhan yang maha esa. Penerapan pembelajaran agama Islam yang didasarkan dari naskah tauhid ini menjadikan masyarakat di Desa Tanjung Sari semakin berkembangan dalam menerapkan ajaran agama Islam.

\section{DAFTAR PUSTAKA}

Abdalati, Hammudah. 1983. Islam Suatu Kepastian. Jakarta: Bumi Aksara

Amaliah, I., Aspiranti, T., \& Purnamasari, P. (2015). "The Impact of the Values of Islamic Religiosity to Islamic Job Satisfaction in Tasikmalaya West Java, Indonesia, Industrial Centre". Procedia-Social and Behavioral Sciences, 211 (September), 984-991. https://doi.org/10.1016/j.sbspro.2015.11.131

Ashaari, M. F., Ismail, Z., Puteh, A., Samsudin, M. A., Ismail, M., Kawangit, R., ... Ramzi, M. I. 2012. "An Assessment of Teaching and Learning Methodology in Islamic Studies". Procedia - Social and Behavioral Sciences, 59, 618-626. https://doi.org/10.1016/j.sbspro.2012.09.322

Baharuddin, E. Bin, \& Ismail, Z. B. 2015. 7 Domains of Spiritual Intelligence from Islamic Perspective. Procedia - Social and Behavioral Sciences, 211(September), 568-577. https://doi.org/10.1016/j.sbspro.2015.11.075.

Baried. Siti Baroroh dkk. 1985. Pengantar Teori Filologi. Jakarta: Pusat Pembinaan dan Pengembangan Bahasa Departemen Pendidikan Dan Kebudayaan.

Burbridge, P., Dixon, J. A., \& Soewardi, B. 1981. "Forestry and agriculture: options for resource allocation in choosing lands for transmigration development". Applied Geography, 1(4), 237-258. https://doi.org/10.1016/0143-6228(81)90010-2

Damayanti, Nuning dan Haryadi Saudi. 2007. "Ragam dan Unsur Spiritualitas pada Ilustrasi Naskah Nusantara 1800-1900an”. ITB J.VIS, Art.1(1): 6684.

Departemen Agama RI. 2002. Islam Untuk Disiplin Ilmu Hukum. Direktorat Jendral Kelembagaan Agama Islam.

Dutney, A. 2007. "Religion, infertility and assisted reproductive technology". Best Practice and Research: Clinical Obstetrics and Gynaecology, 21(1), 169-180. https://doi.org/10.1016/j.bpobgyn.2006.09.007 
Perkembangan Agama ..... Riska Anggraini, Hudaidah, Alian Sair

Gadjahnata, K.H.O dkk. 1986. Masuk dan Berkembangnya Islam di Sumatera Selatan. Jakarta: UI Press

Ghofur, Abd. 2011. "Tela'ah Krisis Masuk dan Berkembangnya Islam di Nusantara". Jurnal Ushulludin.12 (2).

Hariyanto, Joko Tri. 2015. Relasi Agama dan Budaya dalam Hubungan Intern Umat Islam. Penelitian Balai Libang Agama Semarang.

Khotimah. 2014. "Agama dan Civil Society". Jurnal Agama dan Civil Society. 21(1).121132. Diakses pada tanggal 5 Januari 2019.

Kurniawan, R., Mulawarman, A. D., \& Kamayanti, A. (2015). "Biological Assets Valuation Reconstruction: A Critical Study of IAS 41 on Agricultural Accounting in Indonesian Farmers". Procedia - Social and Behavioral Sciences, 164 (August), 68-75. https://doi.org/10.1016/j.sbspro.2014.11.052.

Lutfia, Rizka Agusniar.2013. "Menilik Urgensi Desa di Era Otonomi Daerah”. Jurnal Of Rural and Development. 4 (2)

Masykuri dan Sutrisno Kuntoyo. 1980. Sejarah Pendidikan Sumatera Selatan. Departemen Pendidikan dan Kebudayaan Proyek Inventarisasi dan Dokumentasi Kebudayaan Daerah.

Moons, P., Luyckx, K., Dezutter, J., Kovacs, A. H., Thomet, C., Budts, W., ... Apers, S. 2019. "Religion and spirituality as predictors of patient-reported outcomes in adults with congenital heart disease around the globe". International Journal of Cardiology, 274, 93-99. https://doi.org/10.1016/j.ijcard.2018.07.103.

Nazir, Moh. 2005. Sejarah Peradaban Islam. Bogor Selatan: Ghalia Indonesia.

Rahman, Z. A., \& Shah, I. M. (2015). "Measuring Islamic Spiritual Intelligence". Procedia Economics and Finance, 31 (15), 134-139. https://doi.org/10.1016/S2212-5671(15)01140-5.

Salim, Suna and Syahrul Faizaz. 2015. "Tawheed the Milestone of Islam; A Reflection of Some Prominent Muslim Scholars And Its Implications to Educators". Australian Journal of Basic and Applied Sciences. 9 (1)., Diakses pada tanggal 12 Januari 2019)

Wahyuni, Imelda. 2013. "Pendidikan Islam Masa Pra Islam di Indonesia". Jurnal Al Ta’dib 6 (2). 129-144. Diakses pada tanggal 10 Jaunuari 2019). 